\title{
In vitro conversion of glycerol to lactate with thermophilic enzymes
}

\author{
Chalisa Jaturapaktrarak ${ }^{1}$ Suchada Chanprateep Napathorn ${ }^{1 *}$, Maria Cheng $^{2}$, Kenji Okano $^{2}$, Hisao Ohtake ${ }^{2}$ \\ and Kohsuke Honda ${ }^{2 *}$
}

\begin{abstract}
Background: In vitro reconstitution of an artificial metabolic pathway has emerged as an alternative approach to conventional in vivo fermentation-based bioproduction. Particularly, employment of thermophilic and hyperthermophilic enzymes enables us a simple preparation of highly stable and selective biocatalytic modules and the construction of in vitro metabolic pathways with an excellent operational stability. In this study, we designed and constructed an artificial in vitro metabolic pathway consisting of nine (hyper)thermophilic enzymes and applied it to the conversion of glycerol to lactate. We also assessed the compatibility of the in vitro bioconversion system with methanol, which is a major impurity in crude glycerol released from biodiesel production processes.
\end{abstract}

Results: The in vitro artificial pathway was designed to balance the intrapathway consumption and regeneration of energy and redox cofactors. All enzymes involved in the in vitro pathway exhibited an acceptable level of stability at high temperature $\left(60^{\circ} \mathrm{C}\right)$, and their stability was not markedly affected by the co-existing of up to $100 \mathrm{mM}$ methanol. The one-pot conversion of glycerol to lactate through the in vitro pathway could be achieved in an almost stoichiometric manner, and $14.7 \mathrm{mM}$ lactate could be produced in $7 \mathrm{~h}$. Furthermore, the in vitro bioconversion system exerted almost identical performance in the presence of methanol.

Conclusions: Many thermophilic enzymes exhibit higher stability not only at high temperatures but also in the presence of denaturants such as detergents and organic solvents than their mesophilic counterparts. In this study, compatibilities of thermophilic enzymes with methanol were demonstrated, indicating the potential applicability of in vitro bioconversion systems with thermophilic enzymes in the conversion of crude glycerol to value-added chemicals.

Keywords: in vitro metabolic engineering; thermophilic enzymes; glycerol; methanol

\section{Background}

Integration of diverse biocatalytic modules to construct an advanced microbial cell factory has emerged as a powerful approach for the production of industrially important metabolites [1]. Bioprospecting efforts for exploring novel biocatalytic molecules with unique properties have inspired the design and construction of a wider variety of artificial metabolic pathways [2]. However, installation of an artificially engineered metabolic pathway in living organisms often leads to a competition with natural metabolic pathways for intermediates

\footnotetext{
* Correspondence: Suchada.Cha@chula.ac.th; honda@bio.eng.osaka-u.ac.jp 'Department of Microbiology, Faculty of Science, Chulalongkorn University, Phayathai Road, Patumwan, Bangkok 10330, Thailand

${ }^{2}$ Department of Biotechnology, Graduate School of Engineering, Osaka University, 2-1 Yamadaoka, Suita, Osaka 565-0871, Japan
}

and cofactors, resulting in insufficient yield of desired metabolites. A possible solution to this problem is to avoid the use of living microorganisms and to construct an in vitro artificial metabolic pathway in which only a limited number of enzymes are involved. Until now, a variety of in vitro synthetic pathways have been designed and constructed for the production of alcohols $[3,4]$, organic acids [5,6], carbohydrates [7], hydrogen [8,9], bioplastic [10], and even electricity [11]. Particularly, employment of enzymes derived from thermophiles and hyperthermophiles enables the simple preparation of catalytic modules with excellent selectivity and thermal stability [5,12]. Furthermore, although the detailed mechanisms remain to be clarified, many thermophilic enzymes have also been reported to display higher tolerance towards denaturants such as detergents and

\section{苜}


organic solvents than their mesophilic counterparts $[13,14]$, and activities of some thermophilic enzymes are even improved with organic solvents [15]. These excellent stabilities of thermophilic enzymes allow great flexibility in the operational conditions of in vitro bioconversion systems.

Concerns about the global warming and depletion of fossil fuel reserves have led to the rapid increase of biodiesel production. Generally, $10 \mathrm{~kg}$ of crude glycerol, which is the primary byproduct of the biodiesel industry, is released for every $100 \mathrm{~kg}$ of biodiesel and the growing production of biodiesel has resulted in a worldwide surplus of crude glycerol [16]. Although many studies have been conducted to use crude glycerol as a starting material for the fermentation-based production of industrially valuable chemicals, these attempts often suffer from the inhibitory effects of impurities contained in crude glycerol on the growth and biocatalytic activity of living organisms $[17,18]$. Particularly, methanol, which is the most abundant impurity in crude glycerol, accounts for up to $70 \%(w / w)$ of a raw glycerol obtained through a biodiesel production process [19]. In this study, we focused on the high operational stabilities of thermophilic enzymes and employed them as modules to construct an in vitro synthetic pathway for the conversion of glycerol to lactate, which is one of the most important and versatile biomass-derived chemical [20], in the presence of methanol.

\section{Methods \\ Materials}

Glycerol and methanol were purchased from Wako Pure Chemical Industries Ltd. (Osaka, Japan). Other intermediates of the synthetic pathway, including glycerol-3phosphate (G3P), dihydroxyacetone phosphate (DHAP), glyceraldehyde-3-phosphate (GAP), 3-phosphoglycerate (3-PG), 2-phosphoglycerate (2-PG), phosphoenolpyruvate (PEP), and pyruvate were obtained from Sigma-Aldrich Japan (Tokyo, Japan). NAD ${ }^{+}, \mathrm{NADH}, \mathrm{ADP}$, and ATP were products of Oriental Yeast Co. Ltd. (Osaka, Japan). 2-(4-Iodophenyl)-3-(4-nitrophenyl)-5-(2,4-disulfophenyl)-2H-tetrazolium, monosodium salt (WST-1), and 1-methoxy-5-methylphenazinium methylsulfate (1-methoxy PMS) were purchased from Dojindo Laboratories (Kumamoto, Japan). All other reagents were commercially available and of analytical grade.

\section{Microorganisms and plasmid}

Escherichia coli JM109 was used for general cloning purpose. E. coli Rosetta 2 (DE3) was used for gene expression. Recombinant E. coli was aerobically cultivated at $37^{\circ} \mathrm{C}$ in Luria-Bertani medium supplemented with $100 \mu \mathrm{g} \mathrm{ml}^{-1}$ ampicillin and $34 \mu \mathrm{g} \mathrm{ml}^{-1}$ chloramphenicol. Gene expression was induced by the addition of $0.2 \mathrm{mM}$ isopropyl $\beta$-D-1-thiogalactopyranoside at the late log phase. The expression vector encoding the glycerol kinase of Thermococcus kodakarensis (GK $\mathrm{Gk}_{\mathrm{Tk}}$, gi| 3986088) was donated by Dr. Y. Koga, Osaka University [21]. Sources of expression vectors for triose phosphate isomerase $\left(\mathrm{TIM}_{\mathrm{Tt}}\right.$, gi| 3169211), enolase $\left(\mathrm{ENO}_{\mathrm{Tt}}\right.$, gi| 55979971), pyruvate kinase $\left(\mathrm{PK}_{\mathrm{Tt}}\right.$, gil 55979972), lactate dehydrogenase $\left(\mathrm{LDH}_{\mathrm{Tt}}\right.$, gi| 55981082) of Thermus thermophilus, nonphosphorylating GAP dehydrogenase of T. kodakarensis $\left(\mathrm{GAPN}_{\mathrm{Tk}}\right.$, gi|57640640), and cofactor-independent phosphoglycerate mutase of Pyrococcus horikoshii ( $\mathrm{iPGM}_{\mathrm{Ph}}$, gi| 14589995) were described previously [5]. The expression vector for G3P dehydrogenase of $T$. thermophilus $\left(\mathrm{G} 3 \mathrm{PDH}_{\mathrm{Tt}}\right.$, gi|55981709) was obtained from the Riken T. thermophilus HB8 expression plasmid set [22]. Gene encoding NADH oxidase of Thermococcus profundus $\left(\mathrm{NOX}_{\mathrm{Tp}}\right.$, gi|187453160) was cloned and expressed in $E$. coli as described elsewhere [12].

\section{Analytical method}

Lactate was quantified by high-performance liquid chromatography (HPLC) equipped with two tandemly connected ion exclusion columns (Shim-pack SPR-H, $250 \mathrm{~mm} \times$ $7.8 \mathrm{~mm}$, Shimadzu Corp., Kyoto, Japan). The columns were eluted at $50^{\circ} \mathrm{C}$ using $4 \mathrm{mM} p$-toluenesulfonic acid as a mo-

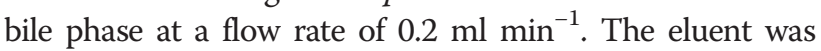
mixed with a pH-buffered solution (16 mM Bis-Tris, $4 \mathrm{mM}$ $p$-toluenesulfonic acid, and $0.1 \mathrm{mM}$ EDTA) supplied at a flow rate of $0.2 \mathrm{ml} \mathrm{min}^{-1}$ and then analyzed for lactate using a conductivity detector (CDD-20A, Shimadzu Corp.). Methanol concentration was quantified by an enzymatic assay using the alcohol dehydrogenase (Sigma-Aldrich Japan) and the horseradish peroxidase (Sigma-Aldrich Japan) according to the protocol provided by the manufacturer.

\section{Enzyme assay}

$E$. coli cells were collected by centrifugation, resuspended in $50 \mathrm{mM}$ HEPES- $\mathrm{NaOH}(\mathrm{pH} \mathrm{7})$, and then disrupted by a UD-201 ultrasonicator (Kubota Corp., Osaka, Japan). After the removal of cell debris by centrifugation, the cell-free extract was incubated at $70^{\circ} \mathrm{C}$ for $30 \mathrm{~min}$. The heat-precipitated proteins were removed by centrifugation, and the resulting supernatant was used as an enzyme solution. One unit of an enzyme was defined as the amount consuming $1 \mu \mathrm{mol}$ of the substrate per min under the below-mentioned standard assay conditions. Protein concentration was measured with the Bio-Rad protein assay kit (Bio-Rad Laboratories Inc., Hercules, CA, USA) using bovine serum albumin as the standard.

Enzyme activities were spectrophotometrically determined at $60^{\circ} \mathrm{C}$ by monitoring consumption or generation of NADH at $340 \mathrm{~nm}$. When necessary, NADH generation 
was coupled with the reduction of WST-1 and detected at $438 \mathrm{~nm}$. GK $\mathrm{Tk}_{\mathrm{Tk}}$ activity was determined by coupling with $\mathrm{G} \mathrm{PDH}_{\mathrm{Tt}}$. The standard assay mixture for $\mathrm{GK}_{\mathrm{Tk}}$ was composed of $50 \mathrm{mM}$ HEPES-NaOH (pH 7), $0.2 \mathrm{mM}$ glycerol, $0.2 \mathrm{mM}$ ATP, $1 \mathrm{mM} \mathrm{NAD}{ }^{+}, 5 \mathrm{mM} \mathrm{MgCl} 2,0.5 \mathrm{mM} \mathrm{MnCl}_{2}$, $0.15 \mathrm{mM}$ WST-1, $6 \mu \mathrm{M}$ 1-methoxy PMS, an excess amount of $\mathrm{G} \mathrm{PDH}_{\mathrm{Tt}}$, and an appropriate amount of $\mathrm{GK}_{\mathrm{Tk}}$. The mixture without glycerol was pre-incubated at $60^{\circ} \mathrm{C}$ for $2 \mathrm{~min}$, and the reaction was initiated by the addition of the substrate. Enzyme reaction was monitored through the reduction of WST-1 to the corresponding formazan dye at $438 \mathrm{~nm}$ using a UV-2450 spectrophotometer (Shimadzu Corp.). G3PDH ${ }_{\mathrm{Tt}}$ assay was performed in the same manner except that $0.2 \mathrm{mM}$ G3P was used as a substrate. TIM $_{\mathrm{Tt}}$ was assayed in a mixture containing $50 \mathrm{mM}$ HEPES-NaOH (pH 7), $0.2 \mathrm{mM}$ DHAP, $1 \mathrm{mM} \mathrm{NAD}{ }^{+}$, $5 \mathrm{mM} \mathrm{MgCl}_{2}, 0.5 \mathrm{mM} \mathrm{MnCl}_{2}, 1 \mathrm{mM}$ glucose-1-phosphate (G1P), an excess amount of $\mathrm{GAPN}_{\mathrm{Tk}}$, and an appropriate amount of the enzyme. After a pre-incubation at $60^{\circ} \mathrm{C}$ for $2 \mathrm{~min}$, the substrate was added to the mixture and the reduction of $\mathrm{NAD}^{+}$was monitored at $340 \mathrm{~nm}$. For the determination of GAPN $\mathrm{Tk}_{\mathrm{Tk}}$ activity, $0.2 \mathrm{mM}$ GAP was used instead of DHAP. Similarly, iPGM $\mathrm{Ph}_{\mathrm{Ph}}$ activity was assessed by coupling with $\mathrm{ENO}_{\mathrm{Tt}}, \mathrm{PK}_{\mathrm{Tt}}$, and $\mathrm{LDH}_{\mathrm{Tt}}$. The enzyme was assayed in a mixture containing $50 \mathrm{mM}$ HEPES$\mathrm{NaOH}$ (pH 7), $0.2 \mathrm{mM}$ 3-PG, $0.2 \mathrm{mM}$ ADP, $0.2 \mathrm{mM}$ $\mathrm{NADH}, 5 \mathrm{mM} \mathrm{MgCl} 2,0.5 \mathrm{mM} \mathrm{MnCl}$, and excess amounts of $\mathrm{ENO}_{\mathrm{Tt}}, \mathrm{PK}_{\mathrm{Tt}}$, and $\mathrm{LDH}_{\mathrm{Tt}}$. The reaction rate was determined by monitoring the concomitant decrease of NADH at $340 \mathrm{~nm}$. Assays for ENO, PK, and LDH were performed in the same mixture using $0.2 \mathrm{mM}$ each of 2PG, PEP, and pyruvate, respectively. $\mathrm{NOX}_{\mathrm{Tp}}$ activity was determined by monitoring the oxidation of NADH under an air atmosphere. A reaction mixture comprising $50 \mathrm{mM}$ HEPES- $\mathrm{NaOH}$ (pH 7.0), $5 \mathrm{mM} \mathrm{MgCl}$, $0.5 \mathrm{mM} \mathrm{MnCl}$, $0.02 \mathrm{mM}$ flavin adenine dinucleotide (FAD), and $0.2 \mathrm{mM}$ $\mathrm{NADH}$ was preincubated at $60^{\circ} \mathrm{C}$ for $2 \mathrm{~min}$ and then the reaction was initiated by adding an appropriate amount of enzyme.

\section{Lactate production}

The reaction mixture $(4 \mathrm{ml})$ was composed of $50 \mathrm{mM}$ HEPES- $\mathrm{NaOH}$ (pH 7), $0.2 \mathrm{mM}$ glycerol, $1 \mathrm{mM} \mathrm{NAD}{ }^{+}$, $0.2 \mathrm{mM}$ NADH, $0.2 \mathrm{mM}$ ATP, $0.2 \mathrm{mM}$ ADP, $0.02 \mathrm{mM}$ FAD, $0.5 \mathrm{mM}$ FBP, $1 \mathrm{mM}$ G1P, $5 \mathrm{mM} \mathrm{MgCl}_{2}$, and $0.5 \mathrm{mM} \mathrm{MnCl}_{2}$. Enzymes were added to the reaction mixture to give the following final concentrations: 0.04 $\mathrm{U} \mathrm{ml}^{-1} \mathrm{GK}_{\mathrm{Tt}}, 0.18 \mathrm{U} \mathrm{ml}^{-1} \mathrm{G} \mathrm{PDH}_{\mathrm{Tt}}, 0.04 \mathrm{U} \mathrm{ml}^{-1} \mathrm{TIM}_{\mathrm{Tt}}$, $0.1 \mathrm{U} \mathrm{ml}^{-1} \mathrm{GAPN}_{\mathrm{Tk}}, 0.09 \mathrm{U} \mathrm{ml}^{-1}$ iPGM $_{\mathrm{Ph}}, 0.07 \mathrm{U} \mathrm{ml}^{-1}$ $\mathrm{ENO}_{\mathrm{Tt}}, 0.09 \mathrm{U} \mathrm{ml}^{-1} \mathrm{PK}_{\mathrm{Tt}}, 0.08 \mathrm{U} \mathrm{ml}^{-1} \mathrm{LDH}_{\mathrm{Tt}}$, and 0.04 $\mathrm{U} \mathrm{ml}^{-1} \mathrm{NOX}_{\mathrm{Tp}}$. The mixture was put in a $10-\mathrm{ml}$ cylindrical vessel and kept at $60^{\circ} \mathrm{C}$ with stirring. Glycerol $(160 \mathrm{mM})$ solution was continuously supplied to the mixture at a flow rate of $1 \mu \mathrm{l} \mathrm{min}{ }^{-1}(0.04 \mu \mathrm{mol}$ glycerol $\mathrm{ml}^{-1} \min ^{-1}$ ) using a Shimadzu LC-20 AD solvent delivery unit. Alternatively, a model solution of crude glycerol, which consisted of $160 \mathrm{mM}$ glycerol and $770 \mathrm{mM}$ methanol, was used as a substrate and fed to the reaction mixture in the same manner. $\mathrm{NAD}^{+}$was put in the substrate solution at $4 \mathrm{mM}$ and supplied into the reaction mixture with the substrate to complement the thermal degradation $\left(0.001 \mu \mathrm{mol} \mathrm{NAD} \mathrm{ml}^{-1} \mathrm{~min}^{-1}\right)$. Aliquots $(50 \mu \mathrm{l})$ of the reaction mixture were sampled at every 1 -h intervals, diluted fourfold with distilled water. The sample was ultrafiltrated using Amicon $3 \mathrm{~K}$ (Merk Milipore, Billerica, MA, USA) and then analyzed by HPLC.

\section{Results and discussion}

\section{Design of the in vitro synthetic pathway}

Figure 1 illustrates the newly designed synthetic pathway for the conversion of glycerol to lactate. To construct an in vitro synthetic pathway, it is vital to prevent the depletion of energy and redox cofactors (ATP/ADP, and $\mathrm{NAD}^{+} / \mathrm{NADH}$ ) by balancing their intrapathway consumption and regeneration. In a previous study, we constructed an ATP/ADP-balanced chimeric EmbdenMeyerhof (EM) pathway by swapping the enzyme couple of GAP dehydrogenase and phosphoglycerate kinase in the bacterial/eukaryotic EM pathway with the nonphosphorylating GAP dehydrogenase $\left(\mathrm{GAPN}_{\mathrm{Tk}}\right)$ involved in the modified EM pathway of a hyperthermophilic archaeon, Thermococcus kodakarensis [5]. Similarly, we employed the GAPN-mediated non-ATP-forming dehydrogenation of GAP to 3-PG for balancing the consumption and regeneration of ATP and ADP through the glycerol converting pathway. On the other hand, the conversion of one molecule of glycerol to lactate through the designed pathway was accompanied by the generation of one molecule of NADH. To re-oxidize the cofactor and to maintain the redox balance of the whole pathway, a hyperthermophilic NADH oxidase was integrated into the pathway. NADH oxidases catalyze the reduction of $\mathrm{O}_{2}$ using NAD (P) $\mathrm{H}$ as a reductant and can be divided into two groups: those catalyzing two-electron reduction of $\mathrm{O}_{2}$ to $\mathrm{H}_{2} \mathrm{O}_{2}$ and those catalyzing four-electron reduction of $\mathrm{O}_{2}$ to $\mathrm{H}_{2} \mathrm{O}$. In this study, we employed the NADH oxidase from T. profundus $\left(\mathrm{NOX}_{\mathrm{Tp}}\right)$, which preferably catalyzes four-electron reduction of $\mathrm{O}_{2}$ [23], to eliminate the inhibitory effects of $\mathrm{H}_{2} \mathrm{O}_{2}$ on enzymes. The chemical equation of the overall reaction through the synthetic pathway can be shown as follows:

$$
\begin{aligned}
& \mathrm{HOCH}_{2} \mathrm{CHOHCH}_{2} \mathrm{OH}+1 / 2 \mathrm{O}_{2} \\
& =\mathrm{CH}_{3} \mathrm{CHOHCOO}^{-}+\mathrm{H}_{2} \mathrm{O}+\mathrm{H}^{+}
\end{aligned}
$$

The standard Gibbs energy change $\left(\Delta G^{\circ}\right)$ of the reaction was calculated to be $-256.4 \mathrm{~kJ} / \mathrm{mol}$. 


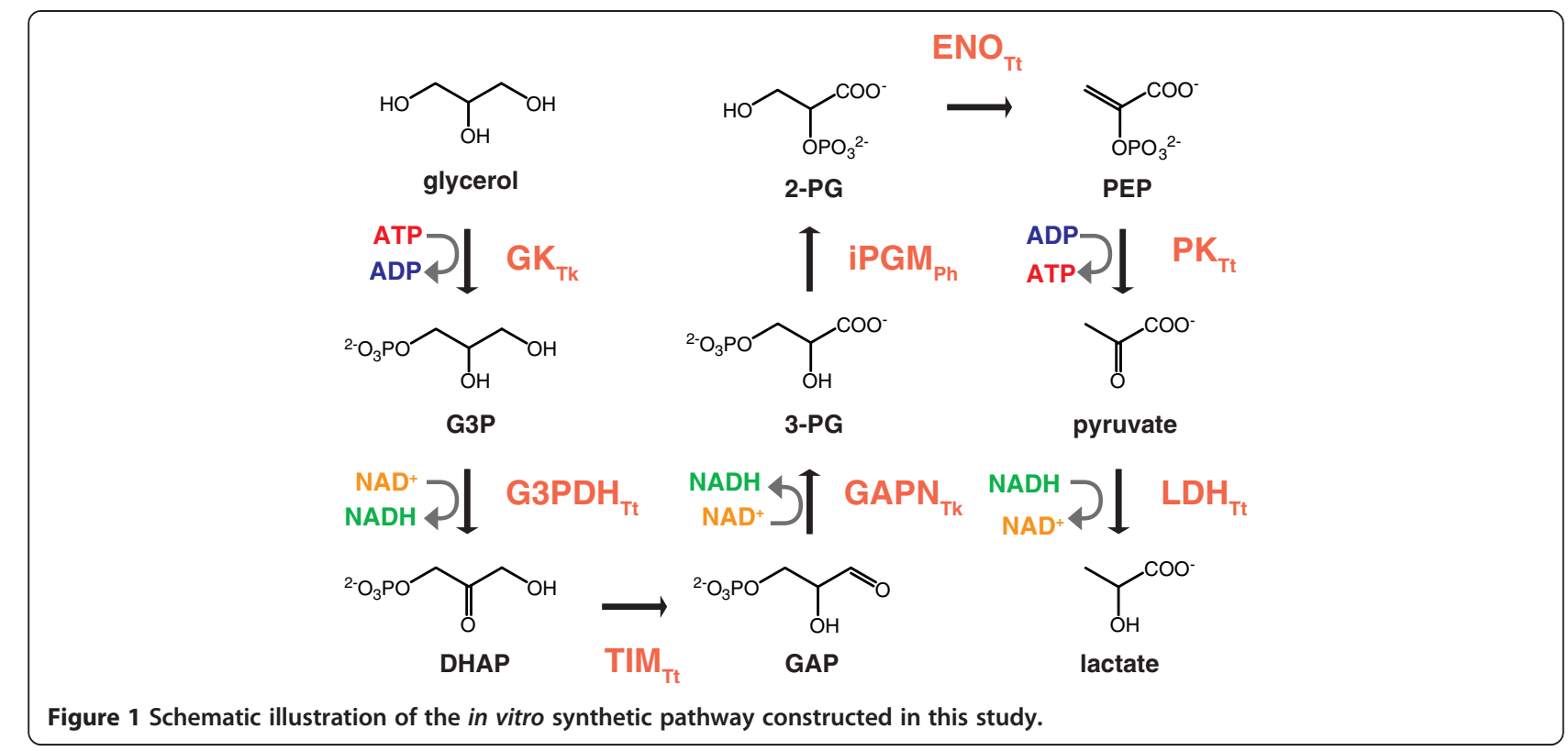

\section{Enzyme stability}

Crude extracts of recombinant $E$. coli cells were heattreated at $70^{\circ} \mathrm{C}$ for $30 \mathrm{~min}$ to denature indigenous proteins and then used in following studies. SDS-PAGE analysis of the crude extract revealed that most of hostderived proteins were removed by the heat precipitation (Additional file 1: Figure S1). The enzyme stability was assessed by measuring the remaining activity of enzymes after the incubation at $60^{\circ} \mathrm{C}$ (Figure 2). Most enzymes could retain more than $80 \%$ of their initial activity for $8 \mathrm{~h}$, except that $\mathrm{PK}_{\mathrm{Tt}}$ lost $35 \%$ of the activity after the incubation for the same time period. We also investigated the effect of methanol, which is the primary impurity contained in crude glycerol, on the enzyme stability. Although residual activities of $\mathrm{TIM}_{\mathrm{Tt}}, \mathrm{iPGM}_{\mathrm{Ph}}, \mathrm{ENO}_{\mathrm{Tt}}$, and $\mathrm{LDH}_{\mathrm{Tt}}$ were moderately lower than those in the absence of methanol (16\% to $32 \%$ decrease), the destabilization profile of other enzymes were not significantly affected by at least up to $100 \mathrm{mM}$ of methanol.

\section{Optimization of reaction conditions}

The lactate production rate through the synthetic pathway was determined at different $\mathrm{pH}$ and temperatures by incubating $0.1 \mathrm{U} \mathrm{ml}^{-1}$ each of $\mathrm{GK}_{\mathrm{Tt}}, \mathrm{G}_{3} \mathrm{PDH}_{\mathrm{Tt}}$, $\mathrm{TIM}_{\mathrm{Tt}}, \mathrm{GAPN}_{\mathrm{Tk}}, \mathrm{iPGM}_{\mathrm{Ph}}, \mathrm{ENO}_{\mathrm{Tt}}, \mathrm{PK}_{\mathrm{Tt}}, \mathrm{LDH}_{\mathrm{Tt}}$, and $\mathrm{NOX}_{\mathrm{Tp}}$ with $10 \mathrm{mM}$ glycerol and appropriate concentrations of cofactors and metal ions (Figure 3). Glucose-1phosphate (G1P) was put in the reaction mixture as an activator for $\mathrm{GAPN}_{\mathrm{Tk}}$ [24]. Although $\mathrm{LDH}_{\mathrm{Tt}}$ is allosterically inhibited by $\mathrm{NAD}^{+}[5]$, lactate dehydrogenases can generally be activated by fructose-1,6-bisphosphate (FBP). In fact, we found that $\mathrm{LDH}_{\mathrm{Tt}}$ activity in the presence of $1 \mathrm{mM} \mathrm{NAD}^{+}$could be recovered to the similar level to that under the standard assay conditions by the addition of $0.5 \mathrm{mM}$ FBP (Table 1). When the reaction was carried out at $60^{\circ} \mathrm{C}$ in different buffers, the highest lactate production rate of $0.036 \mu \mathrm{mol} \mathrm{min} \mathrm{mi}^{-1} \mathrm{ml}^{-1}$ was observed in HEPES-NaOH (pH 7.0) (Figure 3A). The reaction was then performed in this buffer at $50^{\circ} \mathrm{C}, 60^{\circ} \mathrm{C}$, and $70^{\circ} \mathrm{C}$ (Figure 3B). Although no significant difference was observed in production rates at $60^{\circ} \mathrm{C}$ and $70^{\circ} \mathrm{C}$ ( $P>0.1$, Student's $t$-test), the reaction temperature of $60^{\circ} \mathrm{C}$ was employed for further studies to mitigate the thermal inactivation of the enzymes and the decomposition of thermo-labile intermediates and cofactors.

\section{Lactate production}

Unlike highly branched metabolic pathways in living organisms, in vitro synthetic pathways, in which only a limited number of enzyme reactions are sequentially aligned, appear to be less sensitive to the imbalance in enzyme concentrations. Although the existence of a rate-limiting enzyme leads to the accumulation of the specific intermediate, it is eventually converted by downstream enzymes without being routed into the coexisting pathway. However, the accumulation of chemically labile intermediates will result in their spontaneous degradation and decrease in the overall yield of product. We previously demonstrated that the flux through an in vitro metabolic pathway can be spectrophotometrically determined by dividing the whole pathway into some partial pathways, in each of which the $\operatorname{NAD}(\mathrm{H})$ dependent enzymes are assigned to be the last step and by monitoring the concomitant consumption or production of $\mathrm{NAD}(\mathrm{P}) \mathrm{H}$ through the partial pathways [5]. This real-time monitoring technique enables us to identify 

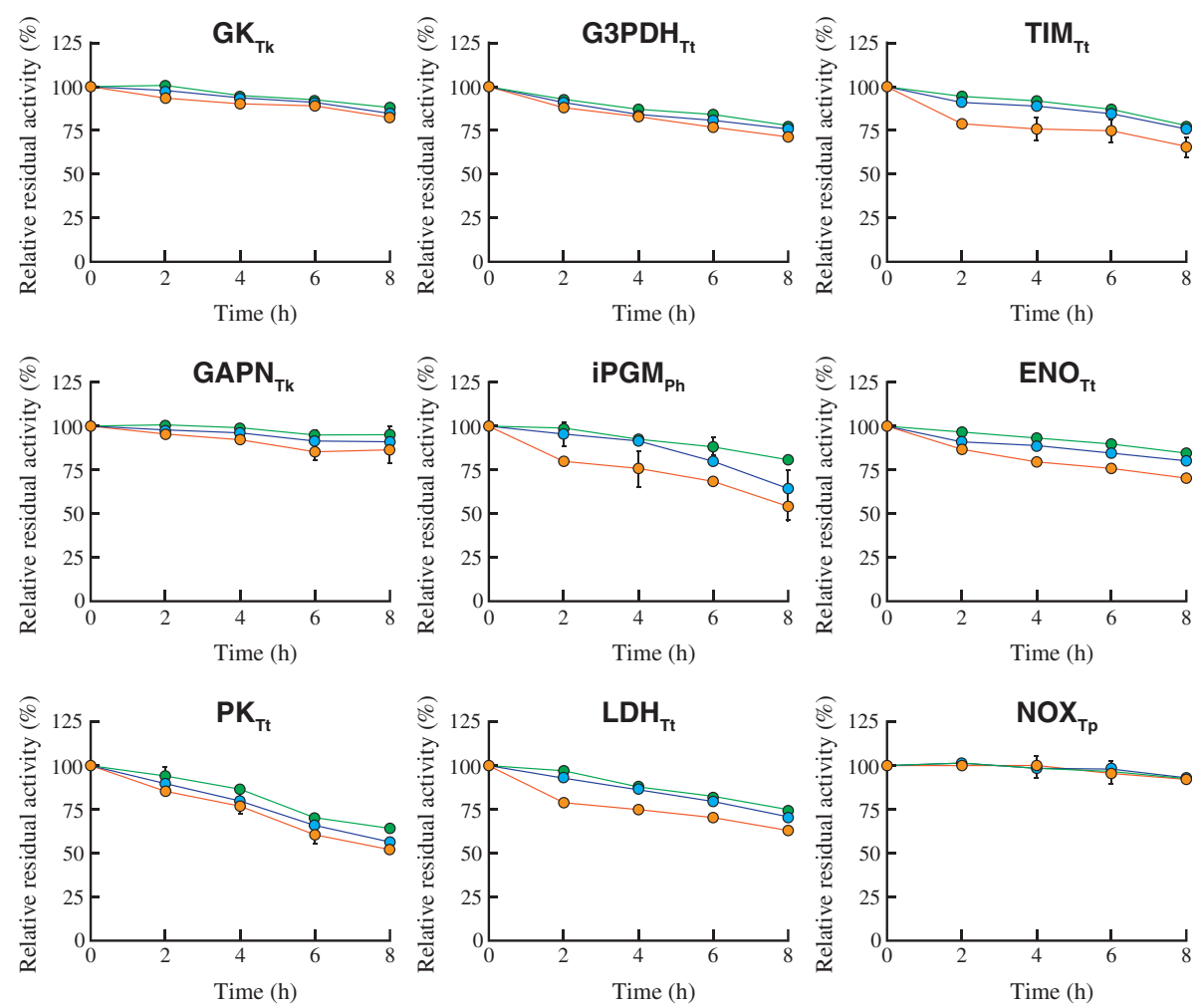

Figure 2 Enzyme stability. Enzyme solutions were incubated at $60^{\circ} \mathrm{C}$ for indicated time periods and residual activities were determined under the standard assay conditions (green circle). Enzyme stabilities were also assessed at $60^{\circ} \mathrm{C}$ in the presence of 50 (blue circle) and $100 \mathrm{mM}$ methanol (orange circle).

rate-limiting enzymes in an in vitro pathway by increasing the concentration of each enzyme, one by one. The optimum concentrations of enzymes to achieve a desired flux can be experimentally determined by modulating the concentrations of the rate-limiting enzymes [4,5]. Accordingly, we divided the glycerol converting pathway in three parts, namely from glycerol to DHAP, from DHAP to 3-PG, and from 3-PG to lactate, and then adjusted the enzyme concentrations in each partial pathway separately. As a result, the optimum enzyme concentrations to achieve a lactate production rate of $0.04 \mu \mathrm{mol} \mathrm{ml}{ }^{-1} \mathrm{~min}^{-1}$ were determined as follows: 0.04 $\mathrm{U} \mathrm{ml}^{-1} \mathrm{GK}_{\mathrm{Tt}}, 0.18 \mathrm{U} \mathrm{ml}^{-1} \mathrm{G} \mathrm{PDH} \mathrm{Tt}_{\mathrm{Tt}}, 0.04 \mathrm{U} \mathrm{ml}^{-1} \mathrm{TIM}_{\mathrm{Tt}}$, $0.1 \mathrm{U} \mathrm{ml}^{-1} \mathrm{GAPN}_{\mathrm{Tk}}, 0.09 \mathrm{U} \mathrm{ml}^{-1}$ iPGM $_{\mathrm{Ph}}, 0.07 \mathrm{U} \mathrm{ml}^{-1}$ $\mathrm{ENO}_{\mathrm{Tt}}, 0.09 \mathrm{U} \mathrm{ml}^{-1} \mathrm{PK}_{\mathrm{Tt}}$, and $0.08 \mathrm{U} \mathrm{ml}^{-1} \mathrm{LDH}_{\mathrm{Tt}}$. Accordingly, $\mathrm{NOX}_{\mathrm{Tp}}$ was put in the reaction mixture to give a NADH re-oxidizing rate of $0.04 \mu \mathrm{mol} \mathrm{ml}^{-1} \mathrm{~min}^{-1}$. A glycerol solution $(160 \mathrm{mM})$ was continuously supplied to the mixture at a rate of $1 \mu \mathrm{l} \mathrm{min}{ }^{-1}$, which is identical to the experimentally determined lactate production rate through the synthetic pathway, to maintain the pool size of the substrate and a constant flux through the pathway. Although the synthetic pathway was designed to achieve the balanced reduction and oxidation of $\mathrm{NAD}^{+}$ and $\mathrm{NADH}$, the thermal decomposition of the cofactors was not negligible (Additional file 2: Figure S2). Owing to this fact, $\mathrm{NAD}^{+}$was also continuously supplied to the reaction mixture at a rate identical to that of its thermal decomposition $\left(0.001 \mu \mathrm{mol} \mathrm{min} \mathrm{m}^{-1} \mathrm{ml}^{-1}\right)$. The lactate production rate could be remained almost constant at the expected level $\left(0.04 \mu \mathrm{mol} \mathrm{min}{ }^{-1} \mathrm{ml}^{-1}\right)$ for the initial $5 \mathrm{~h}$ (Figure 4). Following this, $11.5 \mathrm{mM}$ lactate could be produced with an overall molar conversion yield of 95.5\%. Decrease in the production rate became significant after the initial $5 \mathrm{~h}$, and the conversion yield dropped down to $88 \%$ at $7 \mathrm{~h}$. This appeared partly due to the dilution of the reaction mixture $(10.5 \%$ increase in the total volume at $7 \mathrm{~h}$ ) caused by the continuous feeding of the substrate solution as well as the loss of enzymes by the sampling $(8.8 \%$ decrease in the total concentration at $7 \mathrm{~h})$. Decrease in the production rate might also result from the thermal inactivation of $\mathrm{PK}_{\mathrm{Tt}}$ (Figure 2). Substitution of $\mathrm{PK}_{\mathrm{Tt}}$ with another pyruvate kinase derived from hyperthermophiles with higher optimum growth temperature than $T$. thermophilius may be a possible means for improving the operational stability of the in vitro bioconversion system.

The final lactate concentration after the reaction for $7 \mathrm{~h}$ was $14.7 \mathrm{mM}$. The overall turnover number of ATP/ADP was calculated to be 36.8 , while that of $\mathrm{NAD}^{+} / \mathrm{NADH}$ was 


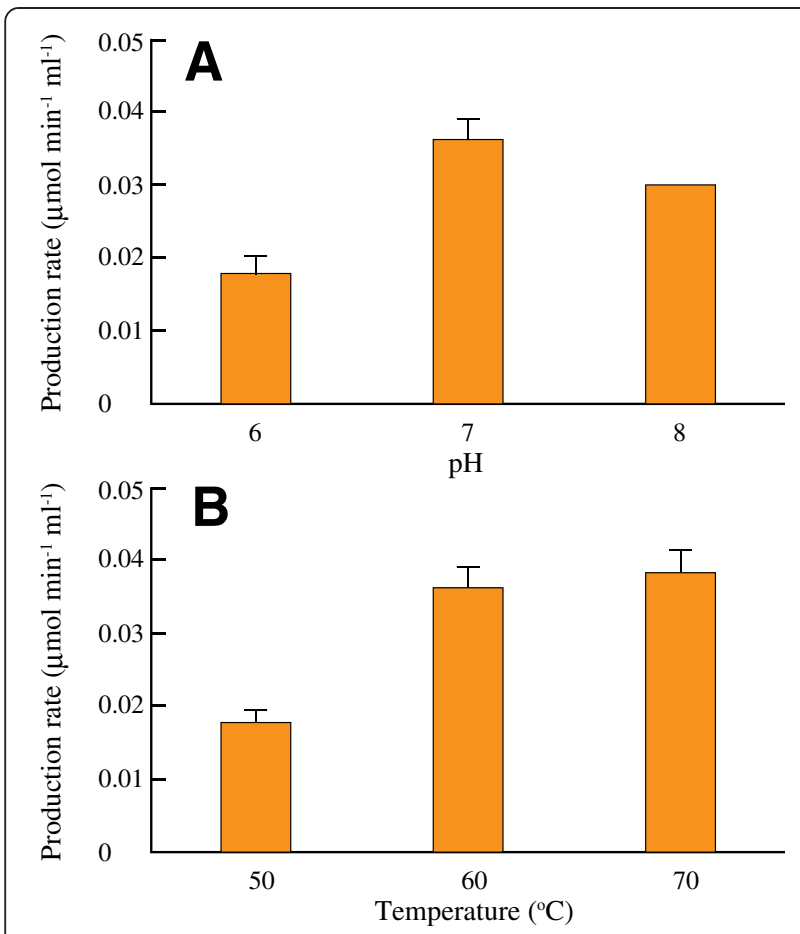

Figure 3 Effects of $\mathrm{pH}(\mathrm{A})$ and temperature (B) on the lactate production through the in vitro synthetic pathway. Enzymes (0.1 $\mathrm{U} \mathrm{ml^{-1 }}$ each) were incubated in a mixture of $10 \mathrm{mM}$ glycerol, $1 \mathrm{mM} \mathrm{NAD}+, 0.2 \mathrm{mM}$ NADH, $0.2 \mathrm{mM}$ ATP, $0.2 \mathrm{mM}$ ADP, $0.02 \mathrm{mM}$ FAD, $0.5 \mathrm{mM} \mathrm{FBP}, 1 \mathrm{mM} \mathrm{G1P}, 5 \mathrm{mM} \mathrm{MgCl} 2,0.5 \mathrm{mM} \mathrm{MnCl}_{2}$, and an appropriate buffer. Reaction was performed at indicated $\mathrm{pH}$ and temperature for $30 \mathrm{~min}$ and then terminated by removing the enzymes with ultrafiltration. Fifty millimolar of MES-NaOH (pH 6) and HEPES-NaOH (pH 7 and 8) were used to adjust $\mathrm{pH}$.

17.5. Enantiomeric purity of the product was determined using a BF- 5 biosensor equipped with a D-lactate quantification unit (Oji Scientific Instruments, Amagasaki, Japan). Concentration of D-lactate in the reaction mixture was under the detection limit (approximately $0.05 \mathrm{mM}$ ), indicating that glycerol was enantio-specifically converted to L-lactate.

\section{Compatibility of the in vitro bioconversion system with methanol}

The chemical composition of crude glycerol is highly varied with the types of catalysts and feedstocks used for

Table 1 Effect of NAD ${ }^{+}$and FBP on the activity of $\mathrm{LDH}_{\mathrm{Tt}}$

\begin{tabular}{lllll}
\hline $\begin{array}{l}\text { FBP } \\
(\mathbf{m M})\end{array}$ & \multicolumn{4}{l}{$\mathbf{N A D}^{+}(\mathbf{m M})$} \\
\cline { 2 - 5 } & $\mathbf{0}$ & $\mathbf{0 . 2}$ & $\mathbf{0 . 5}$ & $\mathbf{1}$ \\
\hline 0 & $192 \pm 4.2$ & $2.51 \pm 0.10$ & $1.08 \pm 0.03$ & $0.31 \pm 0.02$ \\
0.5 & $1,150 \pm 15$ & $980 \pm 3.5$ & $396 \pm 6.2$ & $230 \pm 2.9$ \\
\hline
\end{tabular}

Enzyme assays were performed with and without $0.5 \mathrm{mM}$ FBP in the reaction mixture containing indicated concentrations of $\mathrm{NAD}^{+}$. Results were expressed as specific enzyme activities, which were assessed using a heat-treated cell-free extract and normalized by the protein concentration of the corresponding non-heated cell-free extract $\left(\mathrm{U} \mathrm{mg}^{-1}\right.$ protein). biodiesel production processes [18]. Hansen et al. analyzed the chemical composition of 11 types of crude glycerol obtained from 7 Australian biodiesel manufacturers and revealed that the glycerol content in the crude glycerol varied in the range of $38 \%$ to $96 \%$ and up to $16.1 \%$ of methanol was contained as an impurity [25]. Moreover, Asad-ur-Rehman et al. reported that a raw glycerol obtained during the biodiesel preparation from sunflower oil contained $50 \%$ methanol, which is more abundant than the glycerol content (30\%) [19]. In order to assess the compatibility of the in vitro system with crude glycerol, a model solution of crude glycerol consisting of 30\% (w/v) glycerol and 50\% $(w / v)$ methanol was prepared and used as a substrate for lactate production. The model solution was diluted by distilled water to give a final glycerol concentration of $160 \mathrm{mM}$ (thereby the final methanol concentration was $770 \mathrm{mM}$ ) and supplied into the reaction mixture in the same manner as the lactate production with pure glycerol. The time profile of the lactate production with the model solution was almost identical to that with pure glycerol (Figure 4). After the reaction for $7 \mathrm{~h}$, methanol concentration in the reaction mixture reached $47.8 \mathrm{mM}$, which was significantly lower than the calculated concentration of $80.5 \mathrm{mM}$ probably due to volatilization. These results were in reasonable agreement with our observation that stabilities of most enzymes involved in the synthetic pathway were not markedly affected by up to $100 \mathrm{mM}$ of methanol and demonstrated the potential applicability of in vitro bioconversion systems with

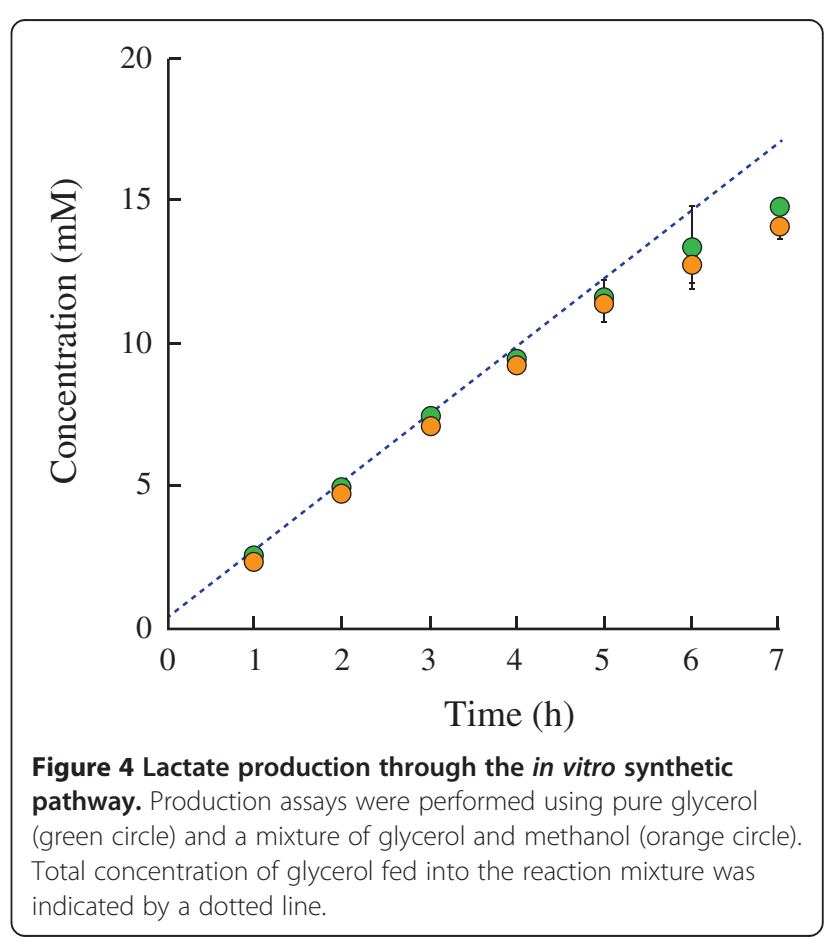


thermophilic enzymes for the conversion of crude glycerol to value-added chemicals.

\section{Conclusions}

In this study, we constructed an artificial in vitro metabolic pathway for the conversion of glycerol to lactate. The in vitro pathway consisted of nine thermophilic and hyperthermophilic enzymes and designed to balance the intrapathway consumption and regeneration of cofactors. The one-pot conversion of glycerol to lactate through the in vitro pathway could be achieved in an almost stoichiometric manner. Although the final product concentration obtained in this study was modest, the overall yield and the production rate of lactate were comparable to those in conventional fermentation processes [20]. Besides, the in vitro bioconversion system can be operated in a simple buffer solution and thus would markedly simplify downstream processes including product recovery and purification. Furthermore, the in vitro bioconversion system exerted almost identical performance in the presence of methanol, demonstrating the potential of thermophilicenzyme-based in vitro metabolic engineering approaches in the utilization of crude glycerol as a starting material for the production of value-added chemicals. On the other hand, although their contents are generally less abundant than those of methanol, crude glycerol contains many other impurities, including fatty acids, soap, and salts. Compatibility tests of thermophilic enzymes with these impurities and the implementation of the in vitro bioconversion with a real crude glycerol would be needed in future studies.

\section{Additional files}

Additional file 1: Figure S1. SDS-PAGE analysis of the crude extracts of recombinant $E$. coli cells. Crude extracts were prepared from approximately $1 \mathrm{mg}$ (wet weight) of the cells overproducing indicated thermophilic enzymes and separated on 12\% acrylamide gels before $(-)$ and after $(+)$ heat treatment at $70^{\circ} \mathrm{C}$ for $30 \mathrm{~min}$. Dual Xtra prestained protein standard (Bio-Rad Laboratories Inc.) was used as a protein marker (lanes indicated by M).

Additional file 2: Figure S2. Thermal decomposition of $N A D^{+}$and $\mathrm{NADH}$. A mixture of $\mathrm{NAD}^{+}(1 \mathrm{mM}$, indicated by blue circle) and $\mathrm{NADH}$ ( $0.2 \mathrm{mM}$, green circle) in $50 \mathrm{mM}$ HEPES- $\mathrm{NaOH}(\mathrm{pH} 7.0)$ was incubated at $60^{\circ} \mathrm{C}$. After the incubation for indicated time periods, residual concentrations of the cofactors were determined by HPLC as described elsewhere (Morimoto et al. 2014). Orange circles indicate the total concentration of $\mathrm{NAD}^{+}$and NADH. Data represent the averages of triplicate assays.

\footnotetext{
Abbreviations

$\mathrm{GK}_{\mathrm{Tt}}$ : glycerol kinase from Thermococcus kodakarensis; $\mathrm{G}_{3} \mathrm{PDH}_{T \mathrm{~T}}$ : glycerol-3phosphate dehydrogenase from Thermus thermophilus; TIMT: triose phosphate isomerase from Thermus thermophilus; $G_{A P N}{ }_{T k}$ : non-phosphorylating glyceraldehyde-3-phosphate dehydrogenase from Thermococcus kodakarensis; iPGMph: cofactor-independent phosphoglycerate mutase from Pyrococcus horikoshii; $\mathrm{ENO}_{\mathrm{Tt}}$ : enolase from Thermus thermophilus; $\mathrm{PK}_{\mathrm{Tt}}$ : pyruvate kinase from Thermus thermophilus; $\mathrm{LDH}_{\mathrm{T}}$ : lactate dehydrogenase from Thermus thermophilus; NOX ${ }_{T p}$ : NADH oxidase from Thermococcus profundus; G3P: glycerol-3-phosphate; DHAP: dihydroxyacetone phosphate; GAP: glyceraldehyde-3-phosphate; 3-PG: 3-phosphoglycerate; 2-PG: 2-phosphoglycerate; PEP: phosphoenolpyruvate;
}

G1P: glucose-1-phosphate; FBP: fructose-1,6-bisphosphate; FAD: flavin adenine dinucleotide; WST-1: 2-(4-iodophenyl)-3-(4-nitrophenyl)-5-(2,4-disulfophenyl)-2Htetrazolium, monosodium salt; 1-methoxy PMS: 1-methoxy-5-methylphenazinium methylsulfate; HPLC: high-performance liquid chromatography.

\section{Competing interests}

The authors declare that they have no competing interests.

\section{Authors' contribution}

CJ performed the experiments and wrote the manuscript. SCN supervised the work and wrote the manuscript. MC co-performed the experiments, particularly on the enzyme stability. $\mathrm{KO}$ and $\mathrm{HO}$ contributed general advice and resource support, as well as edited the manuscript. $\mathrm{KH}$ designed all the experiments and wrote the manuscript. All authors read and approved the final manuscript.

\section{Acknowledgements}

This work was supported in part by the Japan Science and Technology Agency, PRESTO/CREST program. This work was also partly supported by the Japan Society for the Promotion of Science, KAKENHI Grant (26450088). CJ was supported by Japanese Funds-in-Trust, UNESCO Biotechnology School in Asia program and Graduate School Thesis Grant, Chulalongkorn University.

Received: 31 July 2014 Accepted: 6 October 2014

Published online: 28 October 2014

\section{References}

1. Rabinovitch-Deere CA, Oliver JWK, Rodriguez GM, Atsumi S (2013) Synthetic biology and metabolic engineering approaches to produce biofuels. Chem Rev 113:4611-4632

2. Bond-Watts BB, Bellerose RJ, Chang MCY (2011) Enzyme mechanism as a kinetic control element for designing synthetic biofuel pathways. Nat Chem Biol 7:222-227

3. Guterl JK, Garbe D, Carsten J, Steffler F, Sommer B, Reiße S, Philipp A, Haack M, Rühmann B, Koltermann A, Kettling U, Thomas Brück T, Sieber V (2012) Cell-free metabolic engineering: production of chemicals by minimized reaction cascades. ChemSusChem 5:2165-2172

4. Krutsakorn B, Honda K, Ye X, Imagawa T, Bei X, Okano K, Ohtake H (2013) In vitro production of $n$-butanol from glucose. Metab Eng 20:84-91

5. Ye X, Honda K, Sakai T, Okano K, Omasa T, Hirota R, Kuroda A, Ohtake H (2012) Synthetic metabolic engineering - a novel, simple technology for designing a chimeric metabolic pathway. Microb Cell Fact 11:120

6. Ye X, Honda K, Morimoto Y, Okano K, Ohtake H (2013) Direct conversion of glucose to malate by synthetic metabolic engineering. J Biotechnol 164:34-40

7. You C, Chen H, Myung S, Sathitsuksanoh N, Ma H, Zhang XZ, Li J, Zhang YHP (2013) Enzymatic transformation of nonfood biomass to starch. Proc Natl Acad Sci U S A 110:7182-7187

8. Woodward J, Orr M, Cordaray K, Greenbaum E (2000) Enzymatic production of biohydrogen. Nature 405:1014-1015

9. Zhang YHP, Evans BR, Mielenz JR, Hopkins RC, Adams MWW (2007) High-yield hydrogen production from starch and water by a synthetic enzymatic pathway. PLoS ONE 2:e456

10. Opgenorth PH, Korman TP, Bowie JU (2014) A synthetic biochemistry molecular purge valve module that maintains redox balance. Nat Commun 5:4113

11. Zhu Z, Tam TK, Sun F, You C, Zhang YHP (2014) A high-energy-density sugar biobattery based on a synthetic enzymatic pathway. Nat Commun 5:3026

12. Ninn PH, Honda K, Sakai T, Okano K, Ohtake H (2014) Assembly and multiple gene expression of thermophilic enzymes in Escherichia coli for in vitro metabolic engineering. Biotechnol Bioeng (in press)

13. Owusu RK, Cowan DA (1989) Correlation between microbial protein thermostability and resistance to denaturation in aqueous: organic solvent two-phase systems. Enzyme Microb Technol 11:568-574

14. Atomi H (2005) Recent progress towards the application of hyperthermophiles and their enzymes. Curr Opin Chem Biol 9:166-173

15. Pennacchio A, Pucci B, Secundo F, La Cara F, Rossi M, Raia CA (2008) Purification and characterization of a novel recombinant highly enantioselective short-chain $N A D(H)$-dependent alcohol dehydrogenase from Thermus thermophilus. Appl Environ Microbiol 74:3949-3958 
16. Nguyen AQ, Kim YG, Kim SB, Kim CJ (2013) Improved tolerance of recombinant Escherichia coli to the toxicity of crude glycerol by overexpressing trehalose biosynthetic genes (otsBA) for the production of $\beta$-carotene. Bioresour Technol 143:531-537

17. Venkataramanan KP, Boatman JJ, Kurniawan Y, Taconi KA, Bothun GD, Scholz C (2012) Impact of impurities in biodiesel-derived crude glycerol on the fermentation by Clostridium pasteurianum ATCC 6013. Appl Microbiol Biotechnol 93:1325-1335

18. Yang F, Hanna MA, Sun R (2012) Value-added uses for crude glycerol - a byproduct of biodiesel production. Biotechnol Biofuels 5:13

19. Asad-ur-Rehman SWRG, Nomura N, Sato S, Matsumura M (2008)

Pretreatment and utilization of raw glycerol from sunflower oil biodiesel for growth and 1,3-propanediol production by Clostridium butyricum. J Chem Technol Biotechnol 83:1072-1080

20. Okano K, Tanaka T, Ogino C, Fukuda H, Kondo A (2010) Biotechnological production of enantiomeric pure lactic acid from renewable resources: recent achievements, perspectives, and limits. Appl Microbiol Biotechnol 85:413-423

21. Koga Y, Haruki M, Morikawa M, Kanaya S (2001) Stability of chimeras of hyperthermophilic and mesophilic glycerol kinases constructed by DNA shuffling. J Biosci Bioeng 91:551-556

22. Yokoyama S, Matsuo Y, Hirota H, Kigawa T, Shirouzu M, Kuroda Y, Kurumizaka H, Kawaguchi S, Ito Y, Shibata T, Kainosho M, Nishimura Y, Inoue Y, Kuramitsu S (2000) Structural genomics projects in Japan. Nat Struct Biol 7:943-945

23. Jia B, Park S-C, Lee S, Pham BP, Yu R, Le TL, Han SW, Yang J-K, Choi M-S, Baumeister W, Cheong G-W (2008) Hexameric ring structure of a thermophilic archaeon NADH oxidase that produces predominantly $\mathrm{H}_{2} \mathrm{O}$. FEBS J 275:5355-5366

24. Matsubara K, Yokooji Y, Atomi H, Imanaka T (2011) Biochemical and genetic characterization of the three metabolic routes in Thermococcus kodakarensis linking glyceraldehyde 3-phosphate and 3-phosphoglycerate. Mol Microbiol 81:1300-1312

25. Hansen CF, Hernandez A, Mullan BP, Moore K, Trezona-Murray M, King RH, Pluske JR (2009) A chemical analysis of samples of crude glycerol from the production of biodiesel in Australia, and the effects of feeding crude glycerol to growing-finishing pigs on performance, plasma metabolites and meat quality at slaughter. Anim Prod Sci 49(1):54-161

doi:10.1186/s40643-014-0018-4

Cite this article as: Jaturapaktrarak et al: In vitro conversion of glycerol to lactate with thermophilic enzymes. Bioresources and Bioprocessing 2014 1:18.

\section{Submit your manuscript to a SpringerOpen ${ }^{\circ}$ journal and benefit from:}

- Convenient online submission

- Rigorous peer review

- Immediate publication on acceptance

- Open access: articles freely available online

- High visibility within the field

- Retaining the copyright to your article

Submit your next manuscript at $\gg$ springeropen.com 